\title{
Unravelling of Farmers' Existing Crop Nutrient Management Practices: A Baseline Survey of Adopted Village
}

\author{
N. Hema Sarat Chandra ${ }^{1}$, Ch. Ramulu ${ }^{2}$ and G. Swathi ${ }^{1}$ \\ ${ }^{1}$ Department of Agricultural Extension, Agricultural College, Warangal, \\ PJTSAU, 56006, India \\ ${ }^{2}$ Department of Soil Science and Agro Chemicals, RARS- Warangal, PJTSAU, 506006, India \\ *Corresponding author
}

\section{A B S T R A C T}

\begin{abstract}
Village adoption is a scientifically proven method for effective extension service to the farmers. The extension interventions in the village can be planned by considering the Socio economical and agricultural situations prevailed in the village. An attempt was made to understand the village especially the existing crop nutrient management practices of the farmers. Seetharampuram village from Warangal Rural district of Telangana is selected by Regional Agricultural Research Station, Warangal (PJTSAU) to impart technical advices the farmers. A semi structured interview schedule was prepared and Soil samples were collected to analyse the existing crop nutrient management practices of the farmers. Soil analysis report from 203 samples randomly collected by covering throughout the village fields and found that soils are neutral to strong alkaline in reaction $(\mathrm{pH}-7.0-$ 9.06), Non saline to Saline in nature (Ec-0.30-2.95dS/m), organic carbon is low to medium (0.10$0.74 \%)$. Nitrogen is low to medium $(88-339 \mathrm{Kg} / \mathrm{Ha})$ Phosphorus and potassium are medium to very high at $37-228 \mathrm{Kg} / \mathrm{Ha}$ and $297-1309 \mathrm{Kg} / \mathrm{Ha}$ respectively. Based on the responses from 60 randomly selected farmers in the village and considering soil analysis data, there is lot of discrepancy observed from recommended practices to the practices of farmers. Though crop yields are on par to the expectations but there is a lot of scope to reduce the chemical fertiliser usage and cost of cultivation. Trough this study, it has been estimated that, Rs. 8,61,250/- can be saved to the village on soil nutrient management. Besides, interventions towards sustainable agriculture, enhancing technical knowledge to the farmers and counter to depletion of soil nutrients are manifested as a part of technical empowerment in the adopted village.
\end{abstract}

\section{Introduction}

Village adoption is the most effective way of showcasing the benefit of improved crop practices through effective transfer of technology within the stipulated period of adoption (Singh, 2015). It is a development engagement undertaken by an academic / researcher or a development professional who aspires to learn from 'practice' and from the unintended mistakes during the course (Ramesh R et al., 2014). In India, several Non-Governmental Organizations, Financial institution along with Krishi Vignyan Kendras and ICAR institutes have reported the positive impact of their respective village adoption approaches (Chandra et al., 2017). In view to increase the efficiency of the transfer of technology from the Regional Agricultural Research Station, Warangal of Professor 
Jayashankar Telangana State Agricultural University adopted a village Seetharampuram of Damera mandal in Warangal. Baseline survey was conducted in order to know the existing socio economical conditions of the villagers and their crop nutrient management practices. As part of this soil sample survey of the village was conducted to diagnose the existing nutritional composition of the village for farming of various crops. Through this paper an attempt has made to unveil the existing crop nutrition management practices along with their socio economic levels.

\section{Materials and Methods}

This is an exploratory research, simple random sampling was employed to select the respondents to unveil their profile and practices. Seetharampuram village has a population of 820 constituting 203 farm families from which 60 farmers were selected as respondents. Semi structured interview schedule was developed for data collection.

This village has 570 acres of land under cultivation. 203 farm families have been considered for soil survey. Hence, 203 soil samples were collected, processed and analysed to manifest existing soil nutritional and other properties. To estimate availability of Nitrogen, Phosphorous and Potassium in the soil Subbaiah \&Asija method, Olsen's method and Neutral normal ammonium acetate method were used respectively. To estimate availability of Organic carbon in soil Walkley and Black method was used whereas to estimate availability of micro nutrients like $\mathrm{Zn}, \mathrm{Cu}, \mathrm{Mn}$ and $\mathrm{Fe}$ Diethylene triamine penta aceticacid (DTPA) method was used.

\section{Results and Discussion}

The responses of randomly selected 60 farmers from the village were analysed. Based on the data, crops generally grown in this village are Cotton (24.05\%), Maize (22.78\%), Turmeric (17.72\%), Paddy (15.19\%), Chilli $(10.13 \%)$ and Carrot (7.59\%). Banana and water melon were grown to some extent. This village predominantly contains black clay soils (vertisols) and 68.50 percent of irrigated land. Major $(80.00 \%)$ source of irrigation is through open wells. As far as the farmers of Seetharampuram village concern, most of them $(40.00 \%)$ are middle aged (36-50years) followed by $(35.00 \%)$ Young aged (<36years). However, 35.00 per cent are illiterates and most of them are literates. Among the literates, majority $(26.67 \%)$ have education up to intermediate level followed by high school level $(25.00 \%)$. Most of the villagers $(95.00 \%)$ have agriculture as primary source of employment. It could be an opportunity to work with them for their empowerment through agricultural technologies as the young interested farmers with literacy can considerably understand our interventions as well as our intentions. A serious lacuna observed in this village is insufficient reach of public agricultural extension system. This study is evident that most of the farmers are $(93.33 \%)$ frequently seek advice from private input shop-keepers. Therefore, it could be a serious threat to exploit them with various agrochemicals (may be spurious or non-recommended chemicals) and their recommendations which in turn threatens the sustainability of arable land. Hence existing practice of fertilizer application of the farmers is identified through survey and represented in Table 1 and the NPK conversion of fertilizers for various crops is represented in Table 2. There is a lot of discrepancy was observed with the crop and location specific fertilizer recommendations. The farmers are almost not accessing the public agricultural extension system and the services of PJTSAU. This might be one of the reasons, for more adoption gap of agricultural technologies like this nutrient management practices. 
This survey evident that most of the farmers $(81.70 \%)$ have no or very little herd size $(0$ to1) and this could be the reason for insufficient organic manure. Besides this, none of the farmers were aware of using green manure as organic manure. According to the results of diagnosis Seetharampuram village soils are neutral to strong alkaline in reaction (pH-7.0-9.06), Non saline to Saline in nature $(\mathrm{Ec}-0.30-2.95 \mathrm{~d} / \mathrm{m})$, organic carbon is low to medium $(0.10-0.74 \%)$.

Like farmers' responses about existing soil nutrient management practices, in village survey, discrepancy is clearly observed in soil sample analysis. When major nutrients are considered, Nitrogen is low to medium (88$339 \mathrm{Kg} / \mathrm{Ha}$ ) Phosphorus and potassium are medium to very high at $37-228 \mathrm{Kg} / \mathrm{Ha}$ and $297-1309 \mathrm{Kg} / \mathrm{Ha}$ respectively. Per hectare availability of the organic matter and NPK levels is presented in Table 3 .

It is evident from Table 3, most of the soil samples are very high at available phosphorous and potassium Due to more phosphorus levels, deficiency of $\mathrm{Fe}$ is detected in the soils. Soil samples are tested for $\mathrm{Zn}, \mathrm{Cu}, \mathrm{Fe}$ and $\mathrm{Mn}$ and the report witnessed that said micro nutrients are available in the samples $163,1,13$ and 26 respectively. They were deficit in 4, 0, 183 and 0 soil samples. The available micro nutrients are presented in the Table 4 .

According to the respondents of the present study, on an average farmers are applying 30 per cent lesser Nitrogen than recommended for some crops like Maize and Turmeric. But the application of Phosphorous and Potassium were exceeding the recommendation at 30-40 per cent and 10-12 per cent respectively. These observations prove the knowledge gap among the farmers in crop nutrient management. Even though the crop yields are on par to the average yields (Table 5) for the locality, the expenditure on crop nutrient management is on higher side.

Based on the data obtained through this baseline survey, there is a lot of scope to improve the farmers knowledge on crop nutrient management practices. By manifestation of various extension interventions to improve farmers knowledge it is forecasted that, if farmers follow recommended crop nutrient management practices, rupees $8,61,250$ can be saved for the village at fertilizer management. Table 6 clearly explains the discrepancy on crop nutrient management practices in monitory terms.

Table.1 Existing average crop nutrient management in $\mathrm{Kg}$ by the farmers of Seetharampuram village $(\mathrm{n}=60)$

\begin{tabular}{|c|l|c|c|c|c|}
\hline Sl.No & \multicolumn{1}{|c|}{ Crop } & Urea & DAP & MOP & $\mathbf{2 0 - 2 0}$ \\
\hline $\mathbf{1 .}$ & Cotton & 173.68 & 78.95 & 89.47 & 26.32 \\
\hline $\mathbf{2 .}$ & Paddy & 112.50 & 50.00 & 54.17 & 20.83 \\
\hline $\mathbf{3 .}$ & Maize & 105.56 & 36.11 & 36.11 & 72.22 \\
\hline $\mathbf{4 .}$ & Turmeric & 42.86 & 64.29 & 89.29 & 64.29 \\
\hline
\end{tabular}


Table.2 Existing level of NPK application in the Seetharampuram village $(n=60)$

\begin{tabular}{|l|l|c|c|c|}
\hline \multirow{2}{*}{ Sl.No } & \multirow{2}{*}{ Crop } & \multicolumn{3}{|c|}{ Existing level of application of NPK (Kg/Acre) } \\
\cline { 3 - 5 } & & $\mathbf{N}$ & $\mathbf{P}$ & $\mathbf{K}$ \\
\hline $\mathbf{1 .}$ & Cotton & 99 & 41 & 54 \\
\hline $\mathbf{2 .}$ & Paddy & 65 & 27 & 33 \\
\hline $\mathbf{3 .}$ & Maize & 70 & 31 & 22 \\
\hline 4. & Turmeric & 45 & 43 & 54 \\
\hline
\end{tabular}

Table.3 Existing soil nutrient status per hectare of Seethrampuram village $(n=203)$

\begin{tabular}{|c|c|c|c|c|}
\hline \multirow{2}{*}{$\begin{array}{c}\text { Soil Fertility } \\
\text { Level }\end{array}$} & \multicolumn{4}{|c|}{ Distribution of Soil samples } \\
\hline & $\begin{array}{c}\text { Organic } \\
\text { Carbon }(\%)\end{array}$ & $\begin{array}{c}\text { Available N } \\
\text { kg/ha }\end{array}$ & $\begin{array}{c}\text { Available } \mathrm{P}_{2} \mathrm{O}_{5} \\
\mathrm{~kg} / \mathrm{ha}\end{array}$ & $\begin{array}{c}\text { Available } \mathrm{K}_{2} \mathrm{O} \\
\mathrm{kg} / \mathrm{ha}\end{array}$ \\
\hline Very high & - & - & 150 & 203 \\
\hline High & 9 & - & 40 & - \\
\hline Medium & 52 & - & 11 & - \\
\hline Medium low & 100 & 6 & 2 & - \\
\hline Low & 32 & 184 & - & - \\
\hline Very low & 10 & 13 & - & - \\
\hline
\end{tabular}

Table.4 Existing Micro nutrient status in the soil of Seethrampuram village ( $n=203)$

\begin{tabular}{|c|c|c|c|c|}
\hline \multirow{2}{*}{$\begin{array}{l}\text { Soil Fertility } \\
\text { Level }\end{array}$} & \multicolumn{4}{|c|}{ Distribution of Soil Samples } \\
\hline & $\begin{array}{l}\text { Available Zn } \\
\text { (mg/kg) }\end{array}$ & $\begin{array}{l}\text { Available Cu } \\
\text { (mg/kg) }\end{array}$ & $\begin{array}{l}\text { Available Fe } \\
\text { (mg/kg) }\end{array}$ & $\begin{array}{l}\text { Available Mn } \\
\text { (mg/kg) }\end{array}$ \\
\hline Adequate & 36 & 202 & 7 & 175 \\
\hline Marginal & 163 & 1 & 13 & 26 \\
\hline Low & 2 & 0 & 45 & 0 \\
\hline Very low & 2 & 0 & 138 & 0 \\
\hline
\end{tabular}

Table.5 Crop wise Existing average yield obtained by the farmers of Seetharampuram

\begin{tabular}{|l|l|l|}
\hline Sl.No. & \multicolumn{1}{|c|}{ Crop } & Average Yield per acre in quintals \\
\hline 1. & Cotton & 11.38 \\
\hline 2. & Paddy & 23.94 \\
\hline 3. & Maize & 31.94 \\
\hline 4. & Turmeric & 9.50 \\
\hline
\end{tabular}


Table.6 Discrepancy in use of fertiliser to the recommendation on various crops at Seetharampuram Village

\begin{tabular}{|c|c|c|c|c|c|c|c|c|c|c|c|c|c|c|c|c|}
\hline \multirow[t]{2}{*}{$\frac{\stackrel{0}{Z}}{\tilde{\pi}}$} & \multirow[t]{2}{*}{ 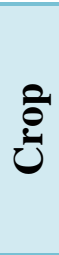 } & \multicolumn{3}{|c|}{$\begin{array}{c}\text { Existing } \\
\text { consumption } \\
\text { pattern of NPK } \\
(\mathrm{Kg}) \text { acre }\end{array}$} & \multicolumn{3}{|c|}{$\begin{array}{l}\text { Soil test based } \\
\text { recommendation } \\
(\mathrm{Kg})\end{array}$} & \multicolumn{3}{|c|}{$\begin{array}{l}\text { Fertilizer saved } \\
\qquad(\mathrm{Kg})\end{array}$} & \multirow[t]{2}{*}{ 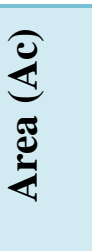 } & \multicolumn{3}{|c|}{$\begin{array}{c}\text { Total fertiliser } \\
\text { incurred/saved }(\mathrm{Kg}) \text { for } \\
\text { total area }\end{array}$} & \multirow{2}{*}{ 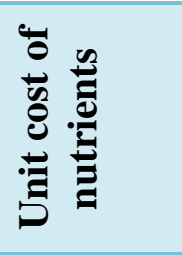 } & \multirow[t]{2}{*}{ 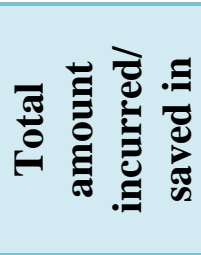 } \\
\hline & & $\mathrm{N}$ & $\mathrm{P}$ & $\mathrm{K}$ & $\mathrm{N}$ & $\mathrm{P}$ & $\mathrm{K}$ & $\mathrm{N}$ & $\mathrm{P}$ & K & & $\mathrm{N}$ & $P$ & $\mathrm{~K}$ & & \\
\hline 1 & 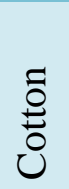 & 99 & 41 & 54 & 63 & 17 & 17 & +36 & +24 & +37 & 250 & +9000 & +6000 & +9250 & $\begin{array}{l}\mathrm{N}=13 / \mathrm{Kg} \\
\mathrm{P}=55 / \mathrm{Kg} \\
\mathrm{K}=20 / \mathrm{Kg}\end{array}$ & $+6,32,000$ \\
\hline 2 & $\frac{\overrightarrow{7}}{\frac{\pi}{\pi}}$ & 65 & 27 & 33 & 52 & 17 & 17 & +13 & +10 & +16 & 50 & +650 & +500 & +800 & & $+51,950$ \\
\hline 3 & 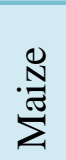 & 70 & 31 & 22 & 104 & 17 & 14 & -34 & +14 & +8 & 100 & -3400 & +1400 & +800 & & $+48,800$ \\
\hline 4 & 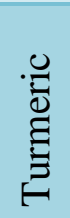 & 45 & 43 & 54 & 90 & 17 & 32 & -45 & +26 & +22 & 100 & -4500 & +2600 & +2200 & & $+1,28,500$ \\
\hline Net a & 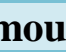 & $\mathbf{o b}$ & . & $1 \mathrm{nt}$ & $n$ & & & 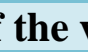 & & & & & & & & $8,61,250 /-$ \\
\hline
\end{tabular}


To get consistent yield performance from the crops, farmers are highly depending upon the synthetic fertilizers by applying them at over dosages. But this practice is not only impacting adversely on cost of cultivation but also on overall soil health and other sustainability parameters. Long term and excessive chemical inputs in soil undoubtedly influence the soil microbial communities in terms of their structural and functional diversity as well as the dominant soil species (Prashar and Shah, 2016). By analysing the facts through this study, it is revealed that application of the fertilizer at recommended dosages not only reduces the cost of cultivation at farmers end but also supports the soil overall health. Soil analysis data obtained from this study supports the findings of over application of phosphorus, deficiency of $\mathrm{Fe}$ occur in the soils. Organic carbon and micronutrient deficit was also found but due to lack of proper knowledge farmers incurring money on fertilizers is more to get the consistency of yields. It has been estimated that, Rs. 8,61,250/- can be saved to the village on soil nutrient management. Farmers' advisory seeking behaviour is also quite disappointing thing. It can be a reason of the discrepancy happened. Hence, interventions to enhance technical knowledge to the farmers are manifested as a part of technical empowerment in the adopted village by Regional Agricultural Research Station, Warangal. Soil health cards were issued along with recommendations after successful testing of soil samples to all farm holders. After that, peripatetic team visits are manifested fortnightly to diagnose various field level problems, recommend scientific practices to ensure the proper agricultural practices in the village adopted.

\section{Acknowledgements}

My sincere thanks to the Dept. of Soil Science \& Regional Agricultural Research Station Warangal, and Agricultural College, Warangal, PJTSAU for involving me to the Village Adoption program.

\section{References}

Chandra, N.H.S., Rudroju, V., Mishra, O.P., 2017. Model Villages and Village Adoption Approaches in the Developmental Arena of Rural India: View and Review, Int. J. Pure App. Biosci. 5(6): 551-557.

Prashar, Pratibha and Shah, Shachi. 2016. Impact of Fertilizers and Pesticides on Soil Micro flora in Agriculture. 10.1007/978-3-319-26777-7_8.

Ramesh R \& Palanithurai, G., 2014. How does Development Takeplace? Journal of Development Management and Communication , $426-436$

Singh, Tarunendu. 2018. "Village Adoption Programme Boosts the Rural Economy". 63. 26.

\section{How to cite this article:}

Hema Sarat Chandra, N., Ch. Ramulu and Swathi, G. 2020. Unravelling of Farmers' Existing Crop Nutrient Management Practices: A Baseline Survey of Adopted Village. Int.J.Curr.Microbiol.App.Sci. 9(06): 3513-3518. doi: https://doi.org/10.20546/ijcmas.2020.906.413 